\title{
Business Analysis on Sustainable Competitive Advantages
}

\author{
Zeyu Wang $^{1}$ \\ ${ }^{1}$ BBA, Shannon School of Business, Cape Breton University, Sydney, Canada
}

\begin{abstract}
With the rapid economic growth and globalization, sustainability begins to play a more and more important role in the strategic management of a company. This paper explains what the sustainability competitive advantages are, and what factors are related to sustainability. It also briefly introduces the sustainable competitive advantages from institutional and resource-based views. In addition, this paper presents that sustainable competitive advantages largely depend on the company's capability to manage the institutional context of resource decision. Sustainable competitive advantages are not only related to internal context, but also related to external environment. This paper explains the link of sustainable competitive advantages in the internal and external environment. In conclusion, it presents the necessary understanding for entrepreneurs to concentrate on factors which influence corporate sustainability beyond numbers in the financial analysis.
\end{abstract}

\section{Introduction}

Nowadays, lots of companies focus on profitability and short-term return of investment and neglect their influences on environment, society and the long-term growth. A better understanding of corporate sustainability and sustainable competitive advantages would empower the company to have a consistent growth. Life spans of small businesses are not long, and most of them would disappear in five years because of the lack of core competence and sustainability. The development of sustainability would transfer into sustainable competitive advantages. Furthermore, the development of sustainability not only brings high profitability for the company, but also helps the company to take responsibility of society and environment [6].

This paper has three parts, including review method, key findings, and conclusion. In the paper, the author would state the review question and search method of the paper. The review question explains the principle of the paper, and the search method presents the logic behind the paper and proves the review of the paper's principle. The key findings are the main parts to state the analysis and findings. In this section, the author would provide brief explanations of the corporate sustainability and how the corporate sustainability contributes to gain corporate competitive advantages. Next, what the sustainable competitive advantages are would be explained as well as how these advantages influence the company's performance and society. In the conclusion part, the author would provide the summary of key findings and demonstrate the importance of sustainability and sustainable competitive advantages to the business [8].

\section{Review Method}

The review question of this paper is what the corporate sustainability and sustainable advantages are, and how to gain the sustainability and sustainable advantages. The paper selects Google Scholar as the database. The first step is to search the definition of sustainability. The author selects two essays which describe the multiple levels and the definitions of corporate sustainability. Next, to present the evidence that how does the sustainability strategy transfer to sustainable competitive advantage, the paper searches for the Walmart's sustainability strategy and the success of obtaining sustainable advantage as a business example. In addition, the institution-based view and resource-based view of sustainable competitive advantages to present sustainable competitive advantages are studied. Finally, the paper combines institutional view and resources-based view to explain how to gain the sustainable advantages.

\section{Key Findings}

Corporate sustainability is an approach aiming to create and maintain long-term stakeholders' value through the implementation of a business strategy which focuses on the ethical, social, environmental, cultural, and economic dimensions of doing business. Furthermore, the corporate sustainability can be also viewed as a new and evolving management paradigm. Although corporate sustainability recognizes that profitability is significant, it also requires company to pursue societal goals related to sustainability development. According to the business journal written by Rupert and Daniel, there are four common corporate sustainability strategies. 
- Introverted-risk mitigation strategy: focus on legal issues about environmental and social aspects in order to minimize illegal risks for the company.

- Extroverted-legitimating strategy: focus on partnership, relationship and license for company's operations.

- Conservative-efficiency strategy: focus on ecoefficiency.

- Visionary-holistic sustainability strategy: focus on internal company's activities, gaining competitive advantages through implementation of corporate sustainability.

The most important thing for the company to develop sustainability strategies is to recognize the range of the sustainability issues. In order to define a consistent sustainability framework, the sustainability aspects are based on popular concepts, and are divided into three dimensions of sustainability development [7].

\subsection{Economic Dimension of Corporate Sustainability}

The economic dimension of corporate sustainability focuses on embracing general aspects of a business that must be respected to remain competitive status in the market for a long time. Usage of corporate sustainability would lead to good financial results of the company, but this does not mean that companies should concentrate on aspects that only focus on the financial report. In fact, economic dimension of corporate sustainability advocates companies to focus on obtaining economic success rather than concentrating on the annual financial report, because lots of economic perspective cannot be shown on the report [7]. There are many economic corporate sustainability strategies/factors such as innovation and technology, collaboration, knowledge management, processes, purchase, sustainability report.

\subsection{Ecological Dimension of Corporate Sustainability}

Ecological dimension of corporate sustainability deals with business activities' influences on the environment, and it focuses on environmentally friendly business activities. Negative environmental impacts are caused by plastic wastes, illegal landfill, emission into air, water and ground, and chemical wastes. Ecological dimension advocates companies to follow the legal and ethical standards and take responsibility for the biological environment. Author Rupter claimed that this dimension is mainly measured by impacts, but within corporate sustainable strategies the focus must be laid on the effects causing these impacts [7].

\subsection{Social Dimension of Corporate Sustainability}

The social dimension of corporate sustainability has a wide range of definition and aspects which can be divided into internal social aspects and external social aspects. It mainly focuses on the ethic and social standards. Internal social aspects include corporate governance, motivation and incentives, health and safety, and human capital development. External social aspects of corporate sustainability include ethical behavior and human rights, controversial activities, corruption and cartel, and corporate citizenship.

\subsection{Multiple Levels of Corporate Sustainability}

Many authors believe that sustainability has many different forms of definitions. "In Concepts and Definitions on CSR and Corporate Sustainability, Van Marrewijk supports this view when he concludes that the one solution fits all definitions for corporate sustainability should be abandoned [4]."

Marco Were and Marcel Van Marrewijk claim that "Each organization should choose its own specific ambition and approach regarding corporate sustainability, matching the organization's aims and intentions and aligned with the organization's strategy, as an appropriate response to the circumstance in which it operates." These two authors have divided corporate sustainability into the following six levels.

1. Pre-corporate sustainability (Red): in this level, companies do not have any ambitions and intentions to gain corporate sustainability. However, some business activities labeled as corporate sustainability may be initiated because of the outside legal forces. Monitoring and reinforcement are essential for companies in this level.

2. Compliance-driven corporate sustainability (Blue): corporate sustainability consists of providing welfare to society. At this level, companies perceive corporate sustainability as the correct behavior and duty.

3. Profit-driven corporate sustainability (Orange): corporate sustainability of the level consists of integration of social, ethical and ecological aspects into business operations and decision-making process, provided it into financial bottom line. The motivation of this level is to increase profitability, because positive customer impressions of corporate sustainability would bring good reputation for the company and product which would transfer sustainability into revenues.

4. Caring corporate sustainability (Green): this level consists of balancing economic, social and ecological concerns. Initiation of corporate sustainability go beyond the legal forces and financial considerations. The motivations are human potential, corporate social responsibilities, and environmental protection.

5. Synergistic corporate sustainability (Yellow): this level consists of a search for well-balanced, functional solutions creating values in economic, social and ecological realms of corporate performance, in a synergistic, win-together approach with all relevant stakeholders.

6. Holistic corporate sustainability (Turquoise): corporate sustainability is fully integrated and embedded in every aspect of the organization, aimed at contributing to the quality and continuation of life of every being and entity. This level of corporate sustainability advocates that every person and organization have responsibility to work on others' wellbeing. 
After the development of corporate sustainability, then company would gain sustainable competitive advantages. For example, technology and innovation can make contribution to the increasing of efficiency and lowering cost. Ecological and social sustainability would help the company to build a positive reputation and brand equity, and a positive working condition to attract intelligent employees.

\section{Discussion}

\subsection{Sustainable Competitive Advantages}

As the beginning of the paper has mentioned, many authors agree that sustainable competitive advantages and sustainability do not have single definitions. In summary, sustainable competitive advantages are advantages which maintain consistent growth of the organization, and they consist of multiple aspects. The paper would take Walmart as an example to explain how to build sustainability and sustainable advantages.

\subsubsection{Take Walmart as an example}

Walmart's sustainability strategy is also called cost leadership strategy which can be described as low cost generic competitive strategy. To adapt a low-cost strategy, Walmart needs efficiency in all aspects of its operations. In 2005, to achieve the strategy, Walmart announced its sustainability goals: to be supplied one hundred percent by renewable energy, to create zero waste, to sell products that sustain people and environment [2]. Hence, the strategy is firstly oriented towards low price and low cost. To reach the strategic goal, Walmart must improve its efficiency in all fields. Then, Walmart planned to build sustainable facilities in 2011. The most significant goal is to build a viable prototype which is twenty-five to thirty percent more energy efficient and will produce up to thirty percent fewer greenhouse gas emissions. Another goal is to decrease the greenhouse gas emissions from Walmart's existing stores, warehouses, clubs and distribution centers around twenty percent. As the exhaustion of fossil fuels, the energy cost would significantly raise in the future, so the sustainable energy efficiency strategy of Walmart will not only help the company lower current costs, but also build a sustainable lower-cost ground for the next several decades. Another area of Walmart business related to sustainable energy is logistic system. Walmart began testing new technologies that can help reduce environmental impact, and that were viable for business, and would provide return for investment. Walmart worked with partners to develop a hybrid-electric truck, which featured a parallel hybrid system based on electrically driven second driven axle. Furthermore, Walmart signed contract with partners to develop clean energy technologies consistently in the future [2].

Another sustainable goal of Walmart is to create zero wastes; Walmart focuses on the three " $\mathrm{R}$ " s-reduce, reuse, and recycle. In order to reduce wastes, Walmart collaborated with suppliers to reduce the wastes from packaging and entering store. This strategy not only impacts the sustainability, but also lowers the company's cost base. If Walmart succeeds in reducing the amount of product package, it will reduce the number of transplantations, and lower logistic costs. Besides, Walmart also worked with suppliers to integrate recycle material and wastes into new product and hence, improve the public environmental awareness of their customers [2].

The figures present the achievements of Walmart's sustainability strategy of 2017.

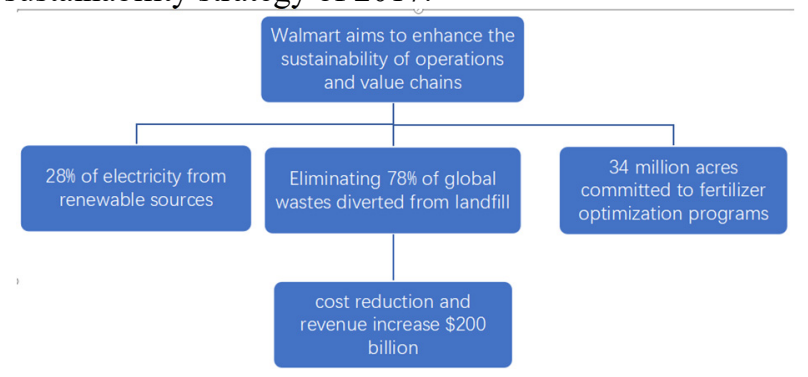

Fig1. Walmart's sustainability strategy of 2017

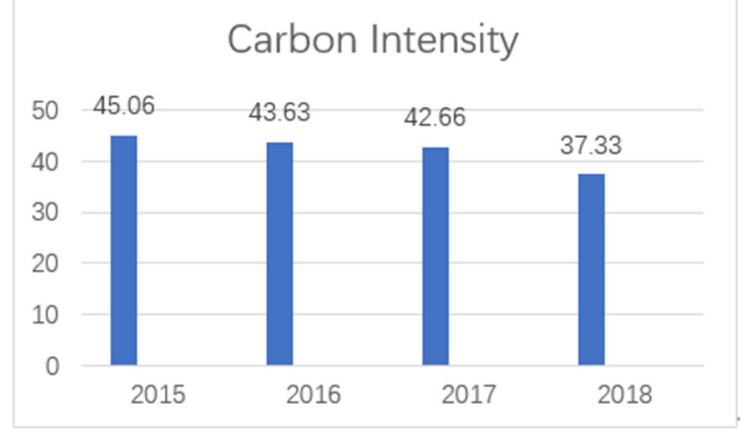

Fig2. Carbon Intensity

Table1. Walmart's Income statement from 2016 to 2018

\begin{tabular}{|c|c|c|c|}
\hline Sales/Revenue & $\mathbf{2 0 1 8}$ & $\mathbf{2 0 1 7}$ & $\mathbf{2 0 1 6}$ \\
\hline Sales Growth & $3.04 \%$ & $0.63 \%$ & - \\
\hline $\begin{array}{c}\text { Cost of Goods Sold } \\
\text { (COGS) incl. D\&A }\end{array}$ & 373,396 & 361,256 & 360,984 \\
\hline $\begin{array}{c}\text { COGS excluding } \\
\text { D\&A }\end{array}$ & 362,867 & 351,176 & 351,530 \\
\hline $\begin{array}{c}\text { Depreciation \& } \\
\text { Amortization } \\
\text { Expense }\end{array}$ & 10,529 & 10,080 & 9,454 \\
\hline $\begin{array}{c}\text { Depreciation } \\
\text { COGS Growth }\end{array}$ & 10,529 & 10,080 & 9,454 \\
\hline $\begin{array}{c}\text { Gross Income } \\
\text { I.36\% }\end{array}$ & 126,513 & 123,888 & 121,146 \\
\hline
\end{tabular}

The figures show the decrease of carbon intensity and increase of revenues of Walmart. Example of Walmart shows that if sustainability is used as a differentiating aspect, a company could find actions that can help the company move towards sustainability, and in this approach differentiate itself in the mind of potential and 
existing customers. At the same time, the same actions could lower the costs base and bring financial return. Walmart achieved its sustainability in all three dimensions. In economic dimensions, the innovation and construction of new logistic system and new technologies of clean energy decrease costs and increase the company's efficiency simultaneously. Thus, it contributes consistent economic growth of the company. In the ecological dimension, the sustainability strategy of Walmart reduces more than fifty percent of greenhouse emissions, and recycles wastes to be new products. In the social dimension, the accomplishment and success strategy of Walmart let competitors and customers pay more attention on environment protection. In other words, Walmart directs a positive social insight about environmental protection in last decades. And social and ecological sustainability bring reputation and brand equity for Walmart and make it to be standards in the retailer industry, which stands for another form of sustainable competitive advantage. Although these sustainable activities could not be expressed on the financial report in short-term, they are key factors to maintain sustainable growth of the company, which are also called sustainable competitive advantages [5].

\subsection{Institutional and Resources-based View of Sustainable Competitive Advantages}

"A resource-based view proposes that resource selection and accumulation are a function of both within-firm decision-making and external strategic factors [1]." Within firm management selections focusing on economic rationality, motives of efficiency, effectiveness and profitability. External factors include buyer and supplier power, intensity of competition, and industry and product market structure. "Whether the resource selection and deployment result in enduring variation across firms will depend on factor market imperfections, defined as barriers to acquisition, imitation, and substitution of key resources or inputs [1]." These barriers enable business to prohibit competitors' imitation or duplication of significant resources and lead to long-term competitive advantage for the firm. Furthermore, based on the characters of resources, companies are supposed to identify whether these resources are scarce, unique, inimitable, durable, idiosyncratic, intangible, non-tradable and nonsubstitutable. Therefore, according to resource-based view, sustainable competitive advantage is the outcome of discretionary rational managerial choices, selective resource accumulation and deployment, strategic industry factors, and factor market imperfections. Based on this view, economic factors drive resources allocation and selections which in turn drive firm's outcomes. Therefore, proper resources selection and allocation have ability to provide sustainable competitive advantage for a company.

"From an institutional perspective, firms operate within a social framework of norm, values, and taken-forgranted assumptions about what constitutes appropriate or acceptable economic behavior. The institutional view suggests that the motives of human behavior extend beyond economic optimization to social justification and social obligation [1]." As a part of social convention, individual and organization should follow the standards and norms of the society, and thus, companies are susceptible and seeking approval to social influence and trend. According this theory, conformity of social rules and expectation contributes the long-term success and survive of the company. Institutional theory states that institutionalized activities are the result of interrelation among individual, organizational, and inter-organizational levels. At the individual level, manager's norm, habits, and unconscious conformity to tradition account for institutionalized activities. At the organizational level, company culture, shared belief among employees and employers, political support process contributes to consistent success of institutionalized structures and behaviors. At the inter-organizational level, pressures from partners, business alliance, social norm, ethics, social expectations define the approval of socially acceptable firm conduct.

\subsection{Brief Summary}

In summary, if companies have capabilities to create healthy working culture and condition, construct corporate beliefs among employees, the company will gain sustainable competitive advantage in institutional perspective. If the company can allocate and select proper resources strategy, it will obtain sustainable competitive advantage in resource perspective.

The key implication of these two views is that firms need both resource capital and institutional capital for long-term sustainable competitive advantage. Theory and research on external sources of competitive advantage should look beyond the resource and market characteristics of firms to government, society, and interfirm relations as important influences on firm variation [1] In summary, the process of acquiring resources and sustaining economic rents is not simply a function of imperfect or incomplete factor markets, but also depend on social context. Social norms, acceptance, and trends will impact the performance of company consistently. In order to gain sustainable competitive advantages, companies are supposed to analyze problems and existing conditions in these two different perspectives and learn how to transfer social acceptance and approval into economic growth. Only one perspective success probably leads to success in short run, but sustainable growth and competitive advantage needs company to consider both [3].

\section{Conclusion}

In conclusion, this project presents the sustainability is a vital factor for any business organization regardless of the size and industry. Furthermore, the corporate sustainability can be divided into three dimensions including economic dimension, ecological dimension, and social dimension. The key implementation of this part is to explain that in order to obtain sustainable competitive advantages, companies need to not only focus on factors and activities presented in financial report, but also factors 
beyond financial report such as working conditions, ethics, and innovations. If the business organization develops a strategy including all three dimensions, the sustainability would be great enough for consistent success. To explain how the sustainability transfer into sustainable competitive advantages, the project analyzes the success of Walmart. Walmart's sustainable strategy to use clean energy and reduce wastes enable it gain sustainability, and these activities also improve efficiency and brand equity, which contribute to sustainable competitive advantages. In the last part of key findings, the project analyzes sustainable competitive advantages in two different views - institution-based view and resource-based view. Institution-based view focuses on social norms, corporate belief and social expectation which cannot be presented in paper report; otherwise, the resource-based view suggests that the importance of selection and allocation of resources in order to obtain sustainable competitive advantage. If a business organization combines the two views to develop its sustainable strategy, it will gain sustainable competitive advantages for consistent growth.

\section{Acknowledgment}

First and foremost, I would like to show my deepest gratitude to my teachers and professors in my university, who have provided me with valuable guidance in every stage of the writing of this thesis. Further, I would like to thank all my friends and roommates for their encouragement and support. Without all their enlightening instruction and impressive kindness, I could not have completed my thesis.

\section{References}

1. C. Oliver, Sustainable Competitive Advantage: combining institutional and resource-based views. Strategic Management Journal, Vol.18:9, pp. 697-713, 1997.

2. E. Stankeviciute, R. Grunda, and Va. Bartkus, Pursing Cost Leadership Strategy and Business Sustainability Objective: Walmart Case Study. Economic and Management, 2012.

3. K. P. Coyne, Sustainable Competitive AdvantageWhat it is, what it isn't. Business Horizons, 1986.

4. M. Van Marrewijk and M. Were, Multiple Levels of Corporate Sustainability. Journal of Business Ethics, 2003.

5. S. H. Liao, C. C. Chen, D. C. Hu, Y. C. Chung, and M.J. Yang, Developing a sustainable competitive advantage: absorptive capacity, knowledge transfer, and organizational learning. The Journal of Technology Transfer, 2016.

6. R. Goodland, The Concept of Environmental Sustainability, Washington DC, 1995.

7. R. J. Baumgartner and Daniela Ebner, Corporate Sustainability Strategies: Sustainability Profiles and Maturity Levels, Wiley InterScience, 2010.

8. S. Bell and S. Morse, Sustainability indicators:
Measuring the Immeasurable? Earth Scan from Routledge, 2008. 